\title{
Resilience of pore-water chemistry and calcification in photosynthetic zones of calcifying sediments
}

\author{
Raphaela Schoon, ${ }^{*}$ Andrew Bissett, ${ }^{1}$ and Dirk de Beer
}

Max-Planck-Institute for Marine Microbiology, Bremen, Germany

\begin{abstract}
Photosynthetically driven calcification was investigated in diatom-dominated carbonate sediments from Bait Reef, Australia. Laboratory measurements conducted over complete diel cycles, using $\mathrm{O}_{2}, \mathrm{pH}, \mathrm{CO}_{3}^{2-}$, and $\mathrm{Ca}^{2+}$ microsensors, confirmed that photosynthesis and respiration drive calcification and calcium release via their respective effects on the local $\mathrm{pH}$. However, the dark situation does not simply mirror the light situation. Profiles showed that calcification and calcium release are not necessarily tightly coupled to the light cycle and that mass transfer phenomena need to be considered in diel chemical dynamics. The magnitude and timing of $\mathrm{pH}$ and $\mathrm{CO}_{3}^{2-}$ concentration changes did not simply follow the light cycle. The $\mathrm{pH}$ in the upper $3 \mathrm{~mm}$ of the sediment changed more rapidly upon illumination than upon darkening. Consequently, photosynthetically induced calcification began shortly (within $1 \mathrm{~h}$ ) after illumination, but the $\mathrm{pH}$ remained elevated and calcification continued for $\sim 7 \mathrm{~h}$ after darkening. Thus, calcification in marine phototrophic sediments is not limited to light periods, but may continue for extended periods after darkening. This decoupling of light, photosynthesis, and calcification has profound consequences for estimates of daily calcification rates, which have previously been made from measurements assuming close to steady states and 12:12 h light:dark calcification and decalcification. In Bait Reef sediments, such an assumption underestimates daily calcification rates by two- to threefold.
\end{abstract}

Carbonate sediments are almost entirely produced by biologically influenced (biogenic) processes (Tucker 1990). Calcification can be controlled at the organismal level, e.g., by the active transport of $\mathrm{H}^{+}, \mathrm{Ca}^{2+}$, and $\mathrm{CO}_{3}^{2-}$ across membranes (de Beer et al. 2000), or at the microenvironmental level by metabolic processes and mass transfer resistances (Bissett et al. 2008b). Organismal calcification can lead to the formation of spectacular and often beautiful structures, such as reefs consisting of corals and various shells, including foraminifera, and for this reason these organisms are often thought to dominate the local habitat. Microenvironmentally controlled calcification, which is mostly driven by microphytobenthos, is, however, less visually spectacular and much less studied, but may be quantitatively important. The main metabolic processes influencing the local carbonate chemistry within coastal surface sediments are photosynthesis and respiration, which may stimulate or depress calcification, respectively.

Carbonate sediments are mainly found in the tropics and subtropics, between $30^{\circ}$ north and $30^{\circ}$ south. Calcification is largely controlled by the carbonate system, and in equilibrium the relative concentrations of $\mathrm{CO}_{2(\mathrm{aq})}, \mathrm{HCO}_{3}^{-}$, and $\mathrm{CO}_{3}^{2-}$ and the $\mathrm{pH}$ value of the system are uniquely linked:

$$
\mathrm{CO}_{2}+\mathrm{H}_{2} \mathrm{O} \stackrel{\mathrm{K}_{1}^{*}}{\leftrightarrow} \mathrm{HCO}_{3}^{-}+\mathrm{H}^{+} \stackrel{\mathrm{K}_{2}^{*}}{\leftrightarrow} \mathrm{CO}_{3}^{2-}+2 \mathrm{H}^{+}
$$

where, $\mathrm{K}_{1}^{*}$ and $\mathrm{K}_{2}^{*}$ are the equilibrium constants. Respiration produces $\mathrm{CO}_{2}$ and shifts the carbonate system to

\footnotetext{
*Corresponding author: rschoon@mpi-bremen.de

${ }^{1}$ Present address: Commonwealth Scientific and Industrial Research Organisation, Plant Industry, Canberra, Australia
}

decreased $\mathrm{CO}_{3}^{2-}$ concentration and $\mathrm{pH}$. Photosynthesis removes $\mathrm{CO}_{2}$ and has the opposite effect. The $\mathrm{pH}$ is the main controller of the precipitation of $\mathrm{CaCO}_{3}$ through its effect on the carbonate ion concentration:

$$
\mathrm{Ca}^{2+}+2 \mathrm{HCO}_{3}^{-} \leftrightarrow \mathrm{CaCO}_{3}+\mathrm{CO}_{2} \uparrow+\mathrm{H}_{2} \mathrm{O}
$$

Calcification releases protons and $\mathrm{CO}_{2}$ and thus buffers to some extent the shifts in pore-water chemistry induced by photosynthesis. The $\mathrm{CaCO}_{3}$ saturation state, $\Omega$, of seawater is defined by:

$$
\Omega=\frac{\left[\mathrm{Ca}^{2+}\right]_{\mathrm{sw}} \times\left[\mathrm{CO}_{3}^{2-}\right]_{\mathrm{sw}}}{\mathrm{K}_{\mathrm{sp}}^{*}}
$$

where $\left[\mathrm{Ca}^{2+}\right]_{\mathrm{sw}}$ and $\left[\mathrm{CO}_{3}^{2-}\right]_{\mathrm{sw}}$ are the concentrations of $\mathrm{Ca}^{2+}$ and $\mathrm{CO}_{3}^{2-}$ in seawater, respectively, and $\mathrm{K}_{\mathrm{sp}}^{*}$ is the stoichiometric solubility product of the carbonate mineral. $\Omega=1$ is the threshold value between under- and oversaturation. As $\mathrm{K}_{\mathrm{sp}}^{*}$ is strongly temperature dependent, tropical surface seawater is, with an $\Omega$ of $\sim 6.1$, much more oversaturated with respect to calcite than polar regions, where $\Omega$ is $\sim 1.7$ (Gattuso et al. 1999). This temperature dependence of $\mathrm{K}_{\mathrm{sp}}^{*}$ largely explains the global distribution of shallow carbonate sediments.

Calcium carbonate can form as aragonite, high-magnesium calcite, or low-magnesium calcite (Morse 2002) in order of importance in shallow marine systems. These calcium carbonate species have different solubilities, whereby higher $\mathrm{Mg}$ content increases solubility.

The coupling of photosynthesis and respiration with calcification and decalcification in calcareous sediments has indeed been directly demonstrated (Werner et al. 2008). Investigations on microbial mats and phototrophic bio- 
films showed that $\mathrm{pH}$ dynamics are slower than $\mathrm{O}_{2}$ dynamics (Revsbech et al. 1983; Kühl et al. 1995). Given the transport limitations of sediments and the fact that $\mathrm{pH}$ is such an essential parameter for calcification, a thorough investigation of the effects of photosynthesis and respiration on sediment $\mathrm{pH}$ dynamics is required for a better understanding and estimation of calcification rates. We investigated the hypothesis that $\mathrm{pH}$ dynamics in diffusionally governed sediments are not tightly linked to illumination and, therefore, that calculations based on $12: 12 \mathrm{~h}$ light: dark periods may lead to inaccurate estimations of calcification. We used $\mathrm{O}_{2}, \mathrm{pH}, \mathrm{CO}_{3}^{2-}$, and $\mathrm{Ca}^{2+}$ microsensors to investigate photosynthesis, respiration, and calcification over complete diel cycles, at high temporal and spatial resolution, in photosynthetically active carbonate sediments from Bait Reef, Australia.

\section{Methods}

Experimental sediments - Sandy sediment was collected from Bait Reef $\left(19^{\circ} 48.201^{\prime} \mathrm{S}, 149^{\circ} 05.052^{\prime} \mathrm{E}\right)$, Australia, at a depth of $18 \mathrm{~m}$ in February 2006. The top $1 \mathrm{~cm}$, which contained most photosynthetic organisms, and the deeper 2 to $5 \mathrm{~cm}$ of the sediment were transported separately. The sediment was transported in $5-\mathrm{L}$ plastic canisters overlaid with $\sim 1 \mathrm{~L}$ ambient seawater to the laboratory in Bremen, Germany, and arrived within $5 \mathrm{~d}$ of sampling. The sediment samples were sulfidic upon arrival.

The sediment was sieved $(125 \mu \mathrm{m})$ to remove infauna and placed in a $5-\mathrm{L}$ glass aquarium, with the original $1-\mathrm{cm}$ photic sediments covering the deeper sediment fraction to a total height of $\sim 5 \mathrm{~cm}$. The porosity was measured with the water evaporation method by weighing before and after drying for $3 \mathrm{~d}$ at $60^{\circ} \mathrm{C}$ (Müller 1964). The aquarium and an external reservoir were filled with $\sim 25 \mathrm{~L}$ artificial seawater (salinity $=34, \mathrm{hw}-$ Meersalz professional, Wiegandt $\mathrm{GmbH}$ ) to a height of $\sim 7 \mathrm{~cm}$ over the sediment. The seawater was recirculated to establish a constant water flow $\left(\sim 0.5 \mathrm{~mL} \mathrm{~cm}^{-2} \mathrm{~s}^{-1}\right)$. Temperature was maintained at 26 $\pm 3^{\circ} \mathrm{C}$. A light-dark cycle of $12: 12 \mathrm{~h}$ with $300 \mu \mathrm{mol}$ photons $\mathrm{m}^{-2}$ total irradiance at the sediment surface (measured with QSL-100, Biospherical Instruments) was established using a metal-halide lamp $(10,000 \mathrm{~K}$, sunlight spectrum, BLV Licht- und Vakuumtechnik $\mathrm{GmbH}$ ). The sediment was left to recover from transport and sieving for 2 weeks before experiments began. The microsensor measurements continued over $\sim 3$ months.

$X$-ray diffraction - The fractions of calcite and aragonite in the sediment were measured. Immediately after the sediment arrived in the laboratory $\sim 5 \mathrm{~g}$ of sediment (top $1-\mathrm{cm}$ depth and 2-5-cm depth) was dried at $60^{\circ} \mathrm{C}$ for $3 \mathrm{~d}$ and ground to a fine powder using a mortar and pestle. The mineralogical composition of the powder was determined by X-ray diffraction using a Philips instrument (control unit PW 3040, goniometer PW 3050, X-ray tube PW 3373/ 00, sample stage PW 1774, monochromator PW 3123/00, detector PW 3011) operating at $40 \mathrm{kV}$ and $30 \mathrm{~mA}$ with monochromated $\mathrm{Cu} \mathrm{K} \alpha$ radiation (5 $\mathrm{s}$ and $0.05^{\circ}$ step).
Pigment analysis-Pigments were extracted from the sediments after the microsensor studies were completed and analyzed according to Buffan-Dubau and Carman (2000), with minor adaptations. Randomly distributed sediment core samples were taken in triplicates with cut-off $10-\mathrm{mL}$ syringes, divided into $2-\mathrm{mm}$ sections, weighed, and transferred to $15-\mathrm{mL}$ centrifuge tubes. Triplicate subsamples ( $\sim 400 \mathrm{mg}$ each) were washed in $2 \mathrm{~mL}$ ice-cold sodium chloride solution $(8 \% \mathrm{NaCl})$, vortexed, and centrifuged for $10 \mathrm{~min}$ at $1800 \times \mathrm{g}$. The sediments were then mixed with $2 \mathrm{~mL}$ ice-cold methanol, sonicated ( $20 \mathrm{~s}$ at $140 \mathrm{~W}$ ), and left for $24 \mathrm{~h}$ at $-20^{\circ} \mathrm{C}$ to extract pigments. After centrifugation for $10 \mathrm{~min}$ at $1800 \times g$ the supernatants were filtered through $0.45-\mu \mathrm{m}$ Acrodisc ${ }^{\circledR}$ CR 4-mm syringe filters (Pall Gelman Laboratory). The complete extraction procedure was carried out on ice and under dim light. The pigments were analyzed using high-performance liquid chromatography, consisting of a Waters 996 photodiode array detector and a Waters 2690 separation module. A $125 \times$ 4.6-mm vertex column, packed with Eurospher- 100 C18 of 5- $\mu \mathrm{m}$ particle size, was used (Knauer $\mathrm{GmbH}$ ). The solvent protocol of Wright and Jeffrey (1997) was employed. The chromatograms were extracted at $430.3 \mathrm{~nm}$, and the pigments were identified and quantified by comparing the retention time and the peak areas with commercially available pigment standards for chlorophyll $a$, fucoxanthin, diadinoxanthin, and $\beta$-carotene (DHI Water and Environment).

Microsensors $-\mathrm{O}_{2}, \mathrm{Ca}^{2+}$, and $\mathrm{pH}$ microsensors were constructed, calibrated, and used as previously described (Revsbech 1989; de Beer et al. 2000). The tip diameters of $\mathrm{pH}$ and $\mathrm{Ca}^{2+}$ microsensors varied between 5 and $15 \mu \mathrm{m}$ and between 25 and $35 \mu \mathrm{m}$ for $\mathrm{CO}_{3}^{2-}$ microsensors. The potentials of the $\mathrm{pH}, \mathrm{Ca}^{2+}$, and $\mathrm{CO}_{3}^{2-}$ sensors were measured against a double liquid-junction reference electrode (Radiometer Analytical).

Microsensors were mounted on a motor-driven micromanipulator with a $1-\mu \mathrm{m}$ positioning accuracy (MM 33, Märzhäuser), which was fixed to a heavy stand. The signals from the amplifiers were recorded on a laptop using a data acquisition device (DAQ-Pad 6020, National Instruments). A custom-made program ( $\mu$-Profiler by L. Polerecky, MaxPlanck-Institute for Marine Microbiology) controlled the motor and data storage.

Profiles for each species were measured over up to three complete diel cycles. Simultaneous measurements with $\mathrm{Ca}^{2+}, \mathrm{pH}, \mathrm{CO}_{3}^{2-}$, and $\mathrm{O}_{2}$ sensors placed in a multiholder (four sensor places) with sensor tips manually aligned to the water surface where performed. Continuous profiles from $2 \mathrm{~mm}$ above the sediment surface to 5-6- $\mathrm{mm}$ sediment depth with a step size of $50-100 \mu \mathrm{m}$ were measured. Each profile measurement lasted $60-90 \mathrm{~min}$.

Steady state was defined as $\leq 2 \%$ deviation in three sequentially measured profiles and was usually reached after $6-10 \mathrm{~h}$ of illumination or darkness. Time to steady state of $\mathrm{O}_{2}, \mathrm{Ca}^{2+}, \mathrm{CO}_{3}^{2-}$, and $\mathrm{pH}$ at a depth of $\sim 1 \mathrm{~mm}$ were quantified by a standard method, where the intercept of the projection of the initial linear increase or decrease (m) after changing the light condition and the final steady 


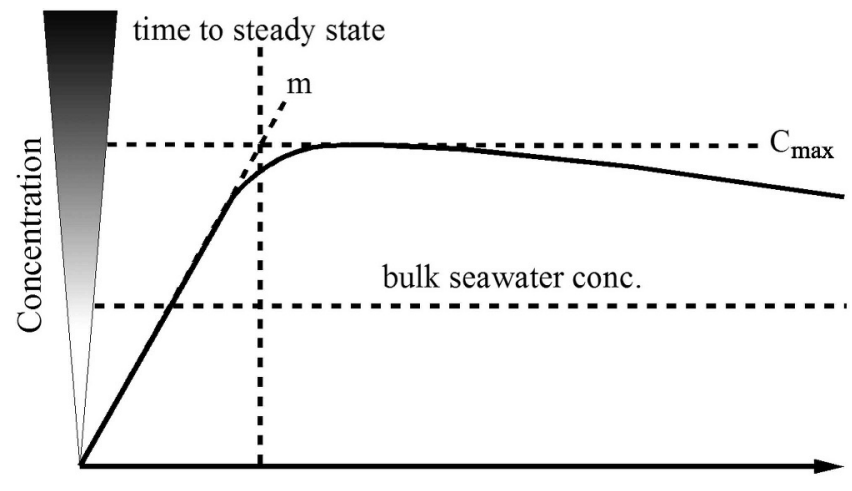

Time (h)

Fig. 1. A sketch of a concentration (e.g., $\mathrm{O}_{2}$ ) dynamics, where $\mathrm{m}$ is the initial increase (or decrease) and $\mathrm{C}_{\max }$ is the maximum (or minimum) concentration in the middle of an illumination period. Time to steady state $(h)$ is the intercept point of $\mathrm{m}$ and $\mathrm{C}_{\max }$.

state concentration $\left(\mathrm{C}_{\max }\right)$ was used as the time to reach steady state (Fig. 1). For $\mathrm{C}_{\max }$ we used three profiles measured around midday, as in the later afternoon the photosynthetic activity decreased.

Total fluxes (J) were calculated with Fick's first law of diffusion:

$$
\mathrm{J}=\mathrm{D} \frac{\partial C}{\partial x}
$$

where $\mathrm{D}$ is the diffusion coefficient and $\partial C / \partial x$ is the spatial concentration gradient. Literature values were used for the diffusion coefficients in water (Broecker and Peng 1974; Li and Gregory 1974) and corrected for temperature, salinity, and porosity $(\Phi)$ with $\mathrm{m}=2$ (for $\Phi \leq 0.7$; Ullman and Aller 1982). The resulting values are summarized in Table 1.

\section{Results}

During the measurements, the sediment was free of bioturbating and bioventilating fauna; thus, transport within sediments was diffusive. The sediment porosity after sieving was 0.43 . A benthic photosynthetic community developed quickly, and after 2 weeks brown and green patches became visible on the sediment surface. These persisted throughout the experimental period. A layer of agglutinated sand grains and algae of $\sim 2$-mm thickness also developed on the sediment surface. Measurements were performed in areas where no gas bubbles or other heterogeneities were observed.

Sediment mineralogy-The top $1 \mathrm{~cm}$ of the sediment consisted of $87 \%$ aragonite and 13\% high-magnesium calcite. The deeper $2-5 \mathrm{~cm}$ consisted of $74 \%$ aragonite and $26 \%$ high-magnesium calcite. All values have a standard error of approximately $\pm 10 \%$. We calculated the $\Omega$ of aragonite $\left(\Omega_{(\mathrm{arag})}\right)$ (Eq. 3; Fig. 2$)$, as this was the major component of $\mathrm{CaCO}_{3}$ observed. The $\mathrm{K}_{\mathrm{sp}}^{*}$, calculated after Zeebe and Wolf-Gladrow (2001), was $6.28 \times 10^{-7}$ $\mathrm{mol}^{2} \times \mathrm{kg}^{-2}$ at a temperature of $24.2^{\circ} \mathrm{C}$ and salinity of 34 .

Pigment analysis - Pigment concentration decreased with depth (Table 2). Pigment profiles were dominated by chlorophyll $a$ and fucoxanthin, with minor amounts of $\beta$ carotene and diadinoxanthin. Fucoxanthin is indicative of diatoms (Wright and Jeffrey 1997), which were the dominant algae in these carbonate sediments. Other pigments were not detected. Microscopic inspection confirmed pigment results and revealed only diatoms to be present.

Steady state analysis-Illumination induced photosynthesis, which had a large effect on the steady state microprofiles of $\mathrm{O}_{2}, \mathrm{pH}, \mathrm{CO}_{3}^{2-}$, and $\mathrm{Ca}^{2+} \cdot \mathrm{O}_{2}, \mathrm{pH}$, and $\mathrm{CO}_{3}^{2-}$ showed maxima in the photosynthetically active zone (top $1 \mathrm{~mm}$ ), where $\mathrm{Ca}^{2+}$ showed a concentration minimum (Fig. 3). Upon darkening, respiration shifted the local chemistry in the opposite direction resulting in a gradual decrease in $\mathrm{O}_{2}$ concentration with depth. $\mathrm{pH}$ and $\mathrm{CO}_{3}^{2-}$ had local minima and $\mathrm{Ca}^{2+}$ a small local maximum, approximately where $\mathrm{O}_{2}$ became depleted $(1 \mathrm{~mm})$. The photosynthetically driven shift in the carbonate equilibria, and the accompanying $\mathrm{pH}$ increase, led to increased values of $\Omega_{(\mathrm{arag})}$, while the opposite occurred in zones where respiration was the net process (Fig. 2).

Total fluxes, calculated from the steady state profiles, are presented in Table 1 . The $\mathrm{O}_{2}$ production by photosynthesis was about one order of magnitude higher than the calcification rate. The $\mathrm{O}_{2}$ respiration rate was of similar magnitude to the calcium release rate.

Table 1. Total steady state fluxes of $\mathrm{O}_{2}$ and $\mathrm{Ca}^{2+}\left(\mathrm{mol} \mathrm{m}^{-2} 0.5 \times \mathrm{d}^{-1}\right) \times 10^{-3}$ and total diel flux $\left(\mathrm{mol} \mathrm{m}^{-2} \mathrm{~d}^{-1}\right) \times 10^{-3}$, assuming $12: 12 \mathrm{~h}$ light: dark. Standard deviation was between $4.9 \times 10^{-4}$ and $5.0 \times 10^{-3}$.* $^{*}$

\begin{tabular}{|c|c|c|c|c|c|c|}
\hline & \multicolumn{3}{|c|}{ Oxygen $(n=3)$} & \multicolumn{3}{|c|}{ Calcium $(n=2)$} \\
\hline & Light & Dark & Diel & Light & Dark & Diel \\
\hline Temperature $\left({ }^{\circ} \mathrm{C}\right)$ & 26.5 & 26.5 & & 23.5 & 23.5 & \\
\hline $\mathrm{D}_{0}\left(\mathrm{~m}^{2} \mathrm{~s}^{-1} \times 10^{-9}\right)$ & 2.33 & 2.33 & & 0.98 & 0.98 & \\
\hline $\mathrm{D}_{\mathrm{s}}\left(\mathrm{m}^{2} \mathrm{~s}^{-1} \times 10^{-9}\right)$ & 1.05 & 1.05 & & 0.44 & 0.44 & \\
\hline Net up & 37.02 & & & -9.23 & 5.56 & \\
\hline Net down & -13.77 & -10.81 & & 3.22 & -1.79 & \\
\hline Net total & 50.62 & -10.81 & 39.81 & -12.45 & 7.35 & -5.10 \\
\hline
\end{tabular}

* $\mathrm{D}_{0}$, free diffusion coefficient; $\mathrm{D}_{\mathrm{s}}$, bulk sediment diffusion coefficient. 
$\Omega$

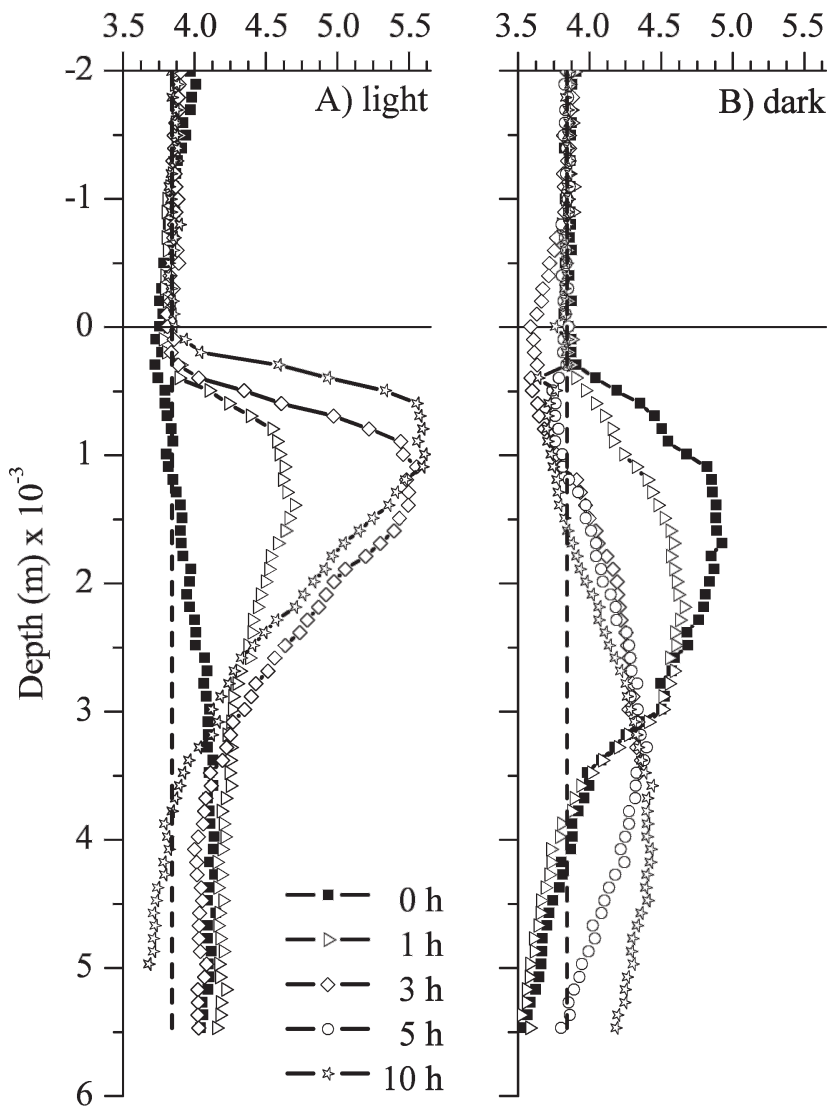

Fig. 2. $\Omega_{(\text {arag) }}$ calculated from calcium and carbonate profiles (A) in the light and (B) in the dark between 0 and $10 \mathrm{~h}$ after condition change. Mean seawater temperature was $24.2^{\circ} \mathrm{C}$ and salinity was $\mathrm{S}=34$. The horizontal line through the depth 0 corresponds to the sediment surface and the vertical dashed line corresponds to the mean seawater $\Omega_{(\mathrm{arag})}$ of 3.84 .

Transient state analyses - The temporal dynamics of $\mathrm{O}_{2}$, $\mathrm{pH}, \mathrm{CO}_{3}^{2-}$, and $\mathrm{Ca}^{2+}$ profiles, in response to illumination and darkening, were different for each species (Figs. 4, 5). $\Omega_{\text {(arag) }}$, calculated from transient pore-water chemistry is presented in Fig. 2. Total integrated (over $12 \mathrm{~h}$ ) $\mathrm{O}_{2}$ and $\mathrm{Ca}^{2+}$ fluxes for complete light and dark intervals are shown in Table 3.

Upon illumination after a $12-\mathrm{h}$ dark period, the time needed to reach steady state of all parameters was similar
(Fig. 5A). $\Omega_{(\mathrm{arag})}$ reached values of $>5.5$ at a depth of $1 \mathrm{~mm}$, which is nearly 1.4 times higher than that in the water column. The $\mathrm{O}_{2}$ penetration depth increased slowly from $\sim 0.5$ to $>6 \mathrm{~mm}$ within $8 \mathrm{~h}$. The $\mathrm{O}_{2}$ concentration decreased slightly after $\sim 8 \mathrm{~h}$ (Fig. 4A). The interfacial fluxes of $\mathrm{O}_{2}$ and $\mathrm{Ca}^{2+}$ became constant within $2-3 \mathrm{~h}$ (Fig. 6). $\Omega_{\text {(arag) }}$ stabilized within $1.8 \mathrm{~h}$, but the position of its peak shifted slightly upwards in the sediment during the following $8 \mathrm{~h}$ (Fig. 2A).

Upon darkening after a 12 -h light period, the time to steady state varied markedly for all dissolved species (Fig. 5B). $\mathrm{O}_{2}$ was consumed within minutes in the sediment's top $2 \mathrm{~mm}$. Deeper layers of the sediment became anoxic within $\sim 1 \mathrm{~h}$ (Fig. 4B). Thus, the removal of $\mathrm{O}_{2}$ in the dark was much faster than its accumulation in the light. In contrast, the $\mathrm{CO}_{3}^{2-}$ concentration and $\mathrm{pH}$ remained elevated for most of the dark cycle (Fig. 4D, F). Following the $\mathrm{pH}$ dynamics, the $\mathrm{Ca}^{2+}$ concentration minimum, which had developed over the light period, also dissipated very slowly (Fig. 4H). Consequently, the $\mathrm{Ca}^{2+}$ flux remained directed into the sediment during the first $7 \mathrm{~h}$ of the dark period (Fig. 6B). Only after $\sim 8 \mathrm{~h}$ did the $\mathrm{Ca}^{2+}$ concentration in the upper $2 \mathrm{~mm}$ increase to its maximum value, at which point the sedimentary calcium concentration was greater than that in the water column, and the influx of $\mathrm{Ca}^{2+}$ changed into an efflux. The $\Omega_{(\mathrm{arag})}$ decreased half as rapidly in the dark as it increased in the light. The times to reach steady state for $\mathrm{pH}$ and $\mathrm{Ca}^{2+}$ profiles were at least 10 times longer than for $\mathrm{O}_{2}$ profiles (Fig. 5B).

\section{Discussion}

Our results show that carbonate sediments inhabited by diatoms perform net calcification (calcification exceeds calcium release). Although photosynthetically induced calcification is driven by light, it does not instantly stop in the dark: the sediment microenvironment remains favorable for calcification for a prolonged time period.

Oceanic surface seawater has an $\Omega_{\text {(arag) }}$ of $\sim 4$ (Zeebe and Wolf-Gladrow 2001) and precipitation of aragonite is favored by high temperature (Milliman 1974). Werner et al. (2008) measured sediment porosities between 0.55 and 0.65 at the Heron Island Reef, Australia. Pigment concentrations measured in freshly sampled sediments from the Whitsunday Region, Australia, were 1.3 and $2.4 \mu \mathrm{g}$ chlorophyll $a \mathrm{~g} \mathrm{~g}^{-1}$ dry weight (Uthicke 2006; Cooper et al. 2007). Thus, despite disturbances by sampling, transporta-

Table 2. Pigment concentrations ( $\mu \mathrm{g} \mathrm{g}^{-1}$ sediment) in sediment depth between 0 and $12 \mathrm{~mm} .^{*}$

\begin{tabular}{|c|c|c|c|c|c|c|c|c|c|c|c|c|}
\hline \multirow[b]{2}{*}{ Depth (mm) } & \multicolumn{3}{|c|}{ Chl $a\left(\mu \mathrm{g} \mathrm{g}^{-1} \mathrm{sed}\right)$} & \multicolumn{3}{|c|}{ Fuco $\left(\mu \mathrm{g} \mathrm{g}^{-1}\right.$ sed $)$} & \multicolumn{3}{|c|}{ Diadino $\left(\mu \mathrm{g} \mathrm{g}^{-1}\right.$ sed $)$} & \multicolumn{3}{|c|}{$\beta$-Car $\left(\mu \mathrm{g} \mathrm{g}^{-1}\right.$ sed $)$} \\
\hline & $n$ & Mean & $\mathrm{SD}$ & $n$ & Mean & $\mathrm{SD}$ & $n$ & Mean & $\mathrm{SD}$ & $n$ & Mean & $\mathrm{SD}$ \\
\hline $0-2$ & 6 & 5.20 & 2.75 & 6 & 2.358 & 0.97 & 3 & 0.133 & 0.01 & 3 & 0.07 & 0.05 \\
\hline $2-4$ & 6 & 0.53 & 0.27 & 6 & 0.210 & 0.15 & 2 & 0.014 & 0.00 & 1 & 0.01 & \\
\hline 4-6 & 3 & 0.13 & 0.03 & 3 & 0.058 & 0.00 & 1 & 0.008 & & 3 & 0.02 & 0.00 \\
\hline $6-8$ & 4 & 0.12 & 0.02 & 4 & 0.054 & 0.01 & 2 & nc & & 2 & 0.02 & 0.00 \\
\hline $8-10$ & 2 & 0.05 & 0.00 & 2 & 0.020 & 0.00 & & & & 1 & 0.03 & \\
\hline $10-12$ & 1 & 0.12 & & 1 & 0.024 & & & & & 1 & 0.03 & \\
\hline
\end{tabular}

\footnotetext{
* Chl $a$, chlorophyll $a$; Fuco, fucoxanthin; Diadino, diadinoxanthin; $\beta$-Car, $\beta$-carotene; $n$, number of replicates; nc, not countable; SD, standard deviation.
} 


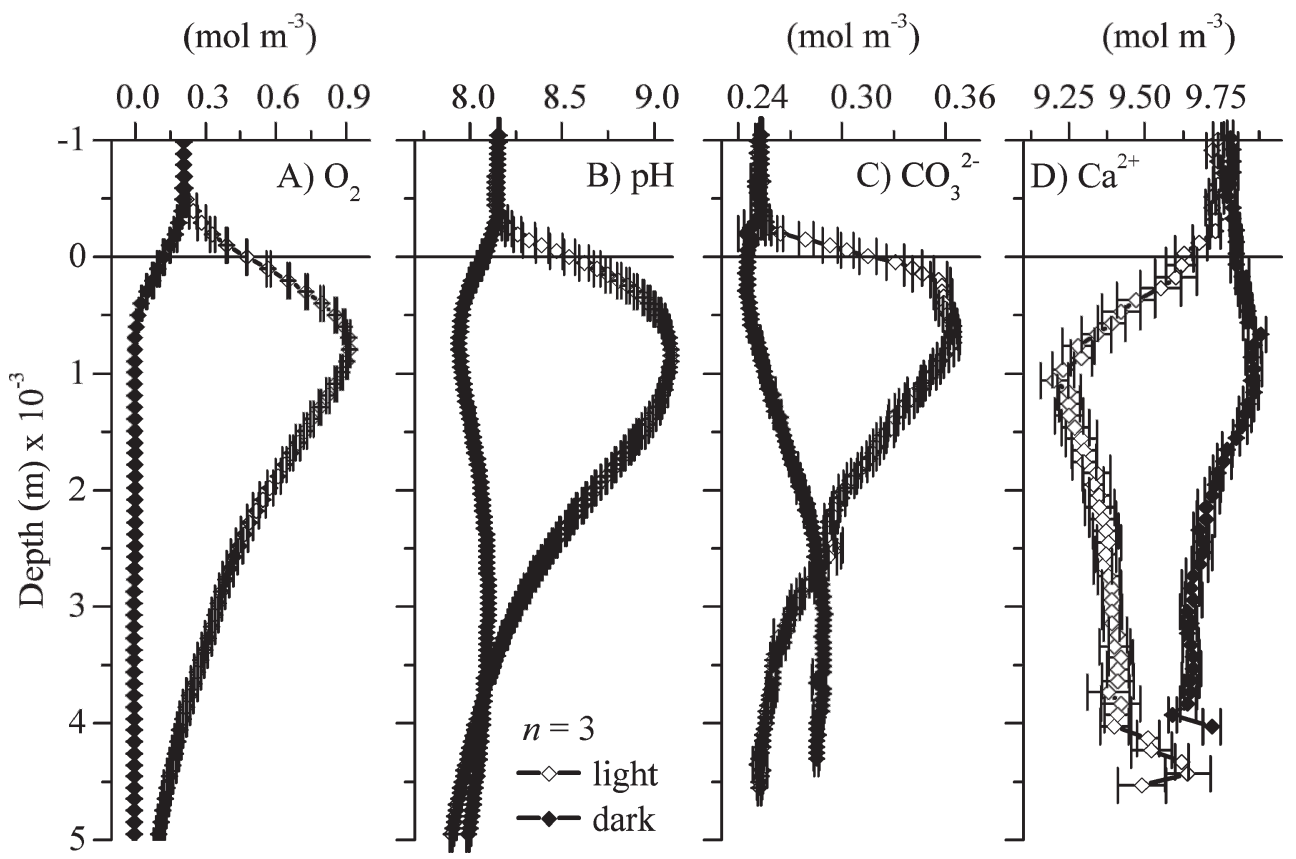

Fig. 3. (A) $\mathrm{O}_{2}$, (B) $\mathrm{pH},(\mathrm{C}) \mathrm{CO}_{3}^{2-}$, and (D) $\mathrm{Ca}^{2+}$ concentration steady state profiles in the light and in the dark. Seawater temperature was $27 \pm 0.5^{\circ} \mathrm{C}$ and salinity was $\mathrm{S}=34$. The horizontal line through the depth 0 represents the sediment surface.

tion, and sieving, our mesocosm was comparable to in situ conditions.

In marine benthic sediments, three possible processes can consume $\mathrm{Ca}^{2+}:$ (1) organismal calcification, involving active transport of $\mathrm{Ca}^{2+}, \mathrm{H}^{+}$, and $\mathrm{CO}_{3}^{2-} ;$ (2) calcification induced by metabolic changes of the microenvironment of sediment interstices, i.e., due to $\mathrm{pH}$-driven shifts in the carbonate system; and (3) $\mathrm{Ca}^{2+}$ binding to extracellular polymeric substances (EPS) (Riding 2000) or other biomass. Organismal calcification, e.g., by foraminifera, can be excluded in the studied sediments, as such organisms were removed by sieving. Binding of $\mathrm{Ca}^{2+}$ to EPS is limited by the availability of binding sites and is, therefore, a transient process (Arp et al. 2001). We observed no reduction in calcium flux over the light period, as would be expected if EPS binding sites became saturated, and therefore consider this pathway of calcium uptake as relatively minimal. However, the small efflux of $\mathrm{Ca}^{2+}$ at the end of the dark period (Fig. 6) may best be explained by binding to EPS, as $\Omega_{(\text {arag })}$ never drops $<3.5$ (Fig. 2), which excludes decalcification. Enzymatic decarboxylation of EPS by bacteria, which reduces the $\mathrm{Ca}^{2+}$ binding capacity (Arp et al. 1998), and the decreased $\mathrm{pH}$ probably induced release of $\mathrm{Ca}^{2+}$ from EPS (Ferris et al. 1989) or biomass. Microenvironmentally driven calcification is the most likely process decreasing the $\mathrm{Ca}^{2+}$ concentration in the pore-water and driving the observed $\mathrm{Ca}^{2+}$ flux into the sediment. Sulfate reduction (SR) may also promote calcium carbonate precipitation (Visscher et al. 1998) but was thought to be unimportant in explaining our observations. High SR rates in reef sediments have been found (Werner et al. 2006). SR may have contributed to alkalinity in our experiments, but SR cannot induce the diel variations observed in $\mathrm{pH}$ and $\mathrm{Ca}^{2+}$ dynamics. For SR to explain the observed prolonged calcification after darkening, it would need to be high in the first hours and then decrease. Previous studies (Ludwig et al. 2005) have, however, shown that SR in hypersaline mats was constant over day and night cycles and that photosynthetically induced $\mathrm{pH}$ and $\mathrm{CO}_{3}^{2-}$ increases, rather than SR, control calcification. The exact fate of the $\mathrm{Ca}^{2+}$ taken up by these sediments is currently under investigation.

The importance of a direct link between metabolism and calcification is clearly demonstrated by the diurnal nature of our profiles. Diatoms are non-calcifying microalgae, which form a silica shell (Lewin and Guillard 1963) but do not perform organismal calcification. Thus, this study on photosynthetically induced calcification in diatom-dominated carbonate sediments demonstrates that in all benthic photosynthetic communities microbially driven calcification can occur.

Microsensor studies on the influence of photosynthesis and respiration on calcification (Hartley et al. 1996; Werner et al. 2008) have already been performed and our data are in the range of the previously published work. Hartley et al. (1996) measured light-induced $\mathrm{Ca}^{2+}$ fluxes in laboratorygrown freshwater biofilms of the unicellular green algae Chlorococcum sp., which were twice as high as the $\mathrm{Ca}^{2+}$ steady state flux measured in this study (Table 1). One reason for the higher $\mathrm{Ca}^{2+}$ flux could be the lower (compared to our study) $\mathrm{pH}$ bulk water starting value of $\mathrm{pH} 8$, which increased to values up to $\mathrm{pH}$ 9.6. $\mathrm{pH}$ values around 9.5 seem to be a kind of threshold value that is not exceeded (Bissett et al. 2008a), where $\mathrm{CO}_{2}$ supply for photosynthesis may become limiting (Bissett et al. 2008b). The higher $\mathrm{pH}$ range from Hartley et al. (1996) refers to higher $\mathrm{CO}_{3}^{2-}$ production and probably also to the higher 


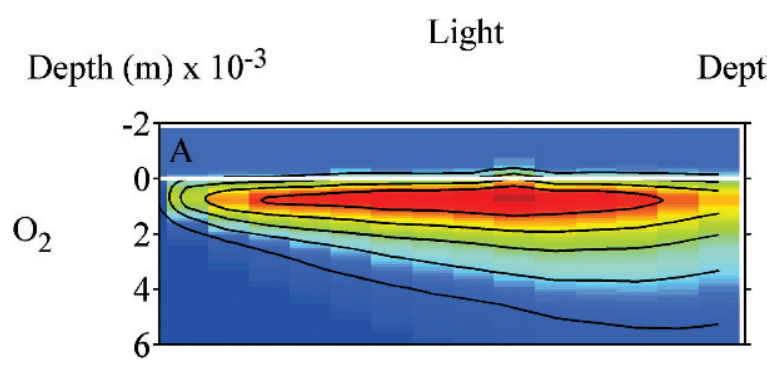

Dark
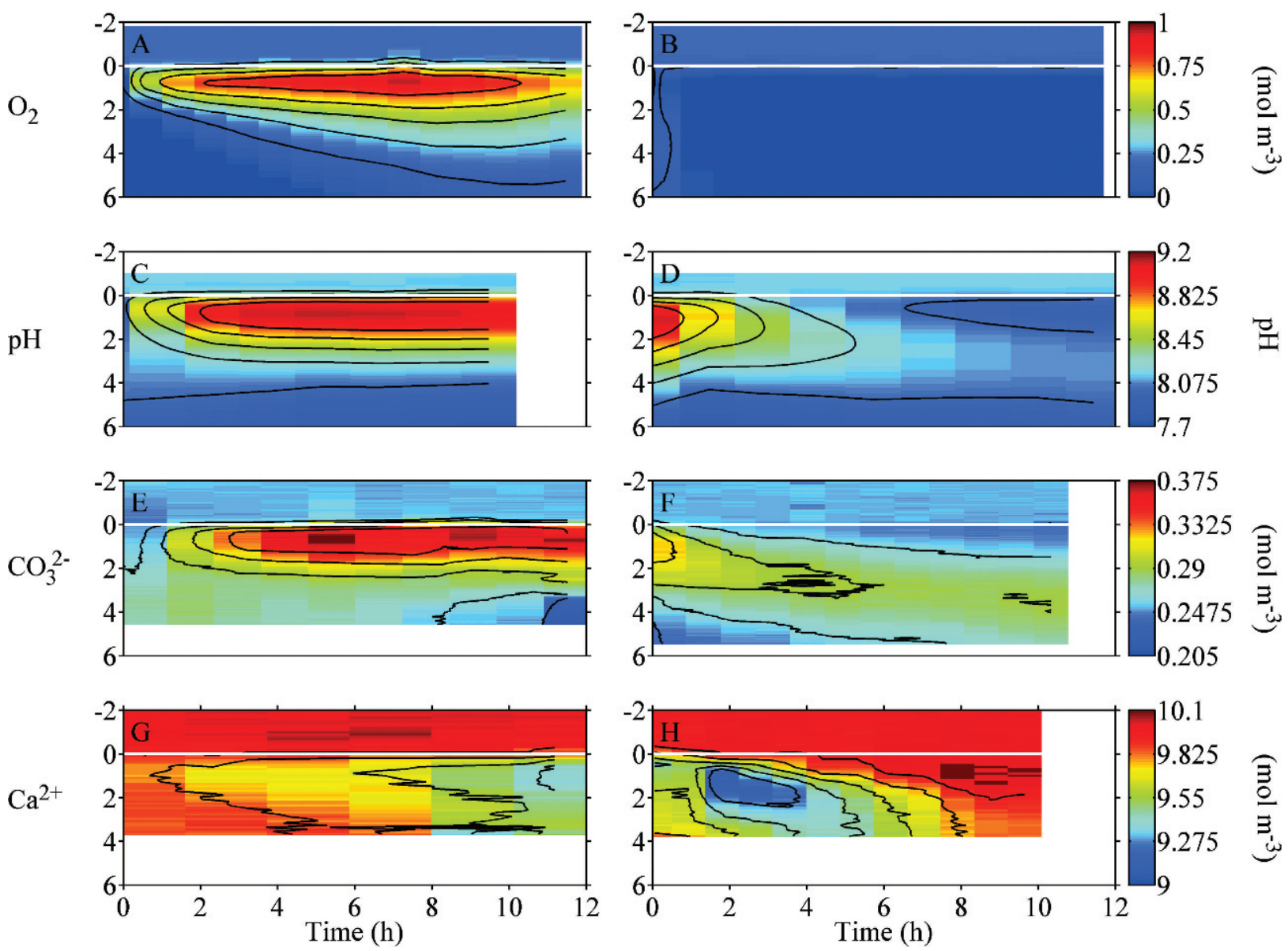

\section{咅}

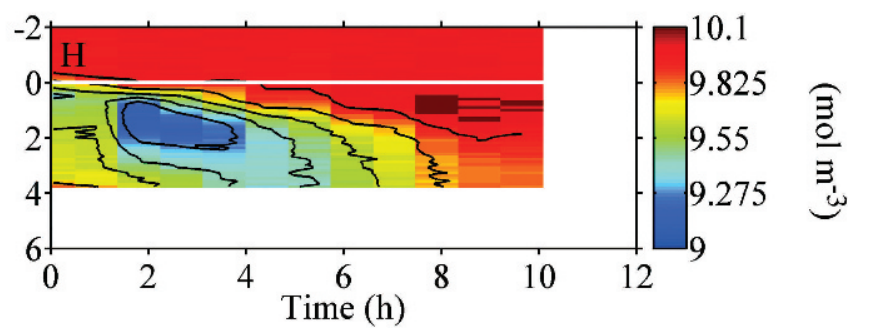

Fig. 4. The distribution of $(\mathrm{A}-\mathrm{B}) \mathrm{O}_{2},(\mathrm{C}-\mathrm{D}) \mathrm{pH},(\mathrm{E}-\mathrm{F}) \mathrm{CO}_{3}^{2-}$, and $(\mathrm{G}-\mathrm{H}) \mathrm{Ca}^{2+}$ in the sediment during a complete light (left side) and dark (right side) cycle. The colors correspond to concentrations as in the color bar on the right. The white line through the depth 0 corresponds to the sediment surface.

calcification rate compared with rates measured in this study.

Our study emphasized the importance of sediments in the reef ecosystem. As we isolated the sediments from the ecosystem and excluded fauna, comparison with field studies is difficult. In situ studies by Boucher et al. (1998) showed light-induced calcification in sediments from the Tiahura barrier reef on the northwest coast of the island of Moorea, French Polynesia. They reported $\mathrm{CaCO}_{3}$ decalcification in the dark. Their studies included effects by fauna which may stimulate decalcification. Gattuso et al. (1996) used the Lagrangian flow respirometry technique to measure calcification rates on three reef flats at Moorea (French Polynesia) and the Yonge Reef (northern half of the Great Barrier Reef). They obtained values which are 20-30 times higher than the diel rates obtained in our study (Table 3). Although the measurements from Gattuso et al. were performed over entire reefs, so including corals and other calcifying organisms, these high rates are remarkable. Yates and Halley (2006) performed in situ measurements in Florida Bay sediments over a period of $27 \mathrm{~d}$ using the alkalinity anomaly technique, and found diel calcification and decalcification, with rates that are in the range of the over diel cycles integrated values we obtained. They found a net calcification over full diel cycles, as in this study.

In principle, on a global scale calcification by photosynthesis must be balanced by decalcification. Generally decalcification occurs below the carbonate compensation depth (Zeebe and Wolf-Gladrow 2001). But it also occurs locally, especially in areas of high organic matter. Walter and Burton (1990), for example reported excess $\mathrm{Ca}^{2+}$ and undersaturated $\Omega_{(\mathrm{arag})}$ in the upper meter of carbonate sediments as evidence of decalcification. The driving force of this decalcification was thought to be organic matter decomposition with moderate SR rates. We did not see decalcification in our samples, as the conditions never reached undersaturation in the top centimeter.

We assumed the system to be in a steady state when the successive profiles changed $<2 \%$, an operational value chosen for the practical reason that it approaches the accuracy of the measurements. Comparison of the transient profiles (Fig. 4) shows that steady state in $\mathrm{O}_{2}$ concentration profiles does not necessarily imply steady state in other parameters, and the timing of the profile measurements can 


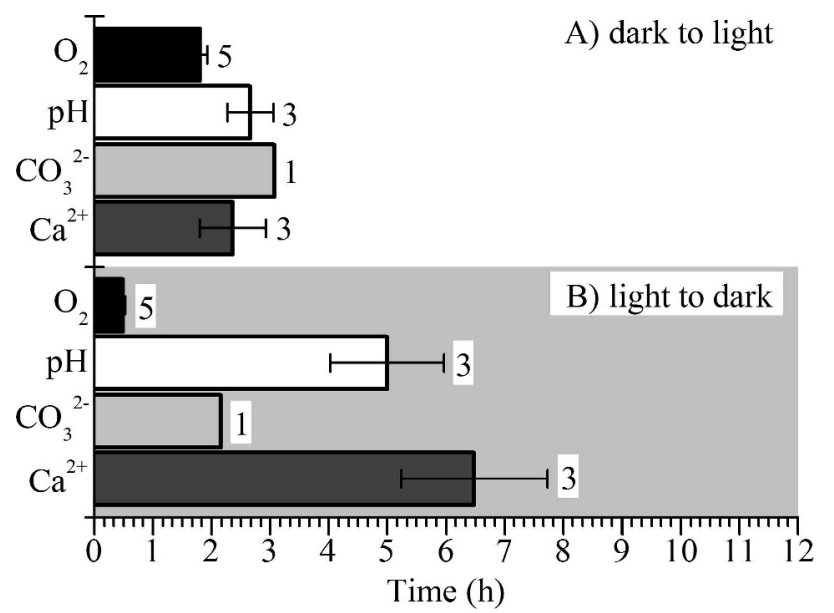

Fig. 5. Time to steady state for $\mathrm{O}_{2}, \mathrm{pH}, \mathrm{CO}_{3}^{2-}$, and $\mathrm{Ca}^{2+}(\mathrm{A})$ after switching on the light (dark [D] to light [L]) and (B) after darkening ( $\mathrm{L}$ to $\mathrm{D}$ ). The numbers in the plot represent the replicate profiles used to determine times to steady state. Mean $\pm \mathrm{SE}$.

drastically affect outcomes. The system can reach different steady states at different times of the day (Fig. 5). A measuring period starting around sunrise would lead to $25 \%$ higher estimation of photosynthetic activity than one beginning at the end of the day. But the calcification rate would be $70 \%$ lower around sunrise than at the end of the day. To use a single set of fluxes, measured during an apparent steady state situation, for an estimation of net budgets during a $12: 12 \mathrm{~h}$ light: dark cycle in diffusionlimited systems, may be very inaccurate. A comparison of steady state fluxes (Table 1) with fluxes integrated over a full light period (Table 3) shows steady state calculations underestimate the true calcification rate by nearly three times, while net photosynthesis is underestimated by $25 \%$.

Upon illumination $\mathrm{O}_{2}$ profiles developed over a period of hours, never really reaching steady state. After $7 \mathrm{~h}$ a maximum $\mathrm{O}_{2}$ concentration was reached and slowly decreased afterwards. Decreases in $\mathrm{O}_{2}$ concentrations late in the light phase of diel cycles are common and are often referred to as the "afternoon depression" (Schanz and Dubinsky 1988). Boucher et al. (1998) showed an afternoon depression in $\mathrm{O}_{2}$ production which was mirrored in $\mathrm{CO}_{2}$ fixation. In this study, the afternoon depression was not very obvious and not visible in the other parameters. The $\mathrm{pH}$ profile became constant after $\sim 3 \mathrm{~h}$ of illumination, and then showed a typical $\mathrm{pH}$ maximum. The $\mathrm{CO}_{3}^{2-}$ and $\mathrm{Ca}^{2+}$ profiles followed the $\mathrm{pH}$ dynamics. The $\mathrm{pH}$ profile in the light was driven by photosynthesis, a process with a high volumetric rate. Thus, calcification could proceed in the light at high rates after the $\mathrm{pH}$ profile established. Upon darkening, respiration led to a dissipation of the $\mathrm{O}_{2}$ profile within $10 \mathrm{~min}$. Oxygen supply to the sediments then became diffusion limited and respiration was therefore limited to the top $0.1 \mathrm{~mm}$. The resulting areal dark respiration rate is much lower than the photosynthesis rate, and thus has much less effect on the $\mathrm{pH}$ dynamics. Whereas photosynthesis led to a $\mathrm{pH}$ maximum at $\sim 1$-mm depth, respiration in the dark occurred much closer to the top of the sediments, and did not directly affect the $\mathrm{pH}$ in the former photosynthetic maximum zone. At that depth the $\mathrm{pH}$ remained elevated during half of the dark period and thus continued to drive calcification. Only after $7 \mathrm{~h}$ in the dark had the $\mathrm{pH}$ profile gradually changed from the typical light situation of high values towards the dark situation of gradually decreasing $\mathrm{pH}$ values with depth (Fig. 4D). From then on calcium release occurred. Preliminary titration experiments (data not shown) demonstrated a higher buffer capacity of sediment than of seawater. Calcification is a result of processes and transport, where processes are varying and transport remains constant. Whereas the $\mathrm{pH}$ dynamics in the light are driven by photosynthesis, a powerful process, the equilibration of the $\mathrm{pH}$ profile in the dark is largely diffusion controlled and not driven by a metabolic process. This explains the different $\mathrm{pH}$ and calcium dynamics upon illumination and darkening.

Our experiments were performed under diffusion-limited conditions. This is often not the case in sandy sediments and the effect of advective transport should also be considered. Advective transport may lead to higher spatial heterogeneity due to ripples, which makes the measurements much more complex (Werner et al. 2006).

Further studies should involve geochemical modeling, including all biogeochemical processes and diffusive as well as advective transport, to allow generalizations of the observations made on our model sediments. Our measurements showed much higher calcification rates than calcium release rates; thus, the sediment observed in our experiments sequestered $\mathrm{CaCO}_{3}$. Unless an anaerobic geochemical process deeper in the sediments leads to decalcification, reef sediments may be net calcifying.

Chemical dynamics in phototrophic calcifying sediments are the result of mass transfer resistances and metabolic processes. Calcification processes, therefore, do not simply follow the light-dark cycle but are influenced by the preceding phase for prolonged periods, thus subject to

Table 3. Over time integrated fluxes of $\mathrm{O}_{2}$ and $\mathrm{Ca}^{2+}$ for light and dark $\left(\mathrm{mol} \mathrm{m}^{-2} 0.5 \times \mathrm{d}^{-1}\right) \times 10^{-3}$ and for diel $\left(\mathrm{mol} \mathrm{m}^{-2} \mathrm{~d}^{-1}\right) \times$ $10^{-3}(n=1)$, and fluxes from $\sim 1.5 \mathrm{~h}$ after sunrise or sunset lasting for $3 \mathrm{~h}$ and integrated over half a day $\left(\mathrm{mol} \mathrm{m}^{-2} 0.5 \times \mathrm{d}^{-1}\right) \times 10^{-3}$. Data from Fig. 6.

\begin{tabular}{|c|c|c|c|c|c|c|}
\hline & \multicolumn{3}{|c|}{ Oxygen } & \multicolumn{3}{|c|}{ Calcium } \\
\hline & Light & Dark & Diel & Light & Dark & Diel \\
\hline Integrated flux & 41.32 & -9.90 & 31.41 & -7.53 & -4.86 & -12.39 \\
\hline Flux around sunrise or sunset & 50.91 & -11.44 & 39.47 & -7.95 & 4.16 & -3.79 \\
\hline
\end{tabular}




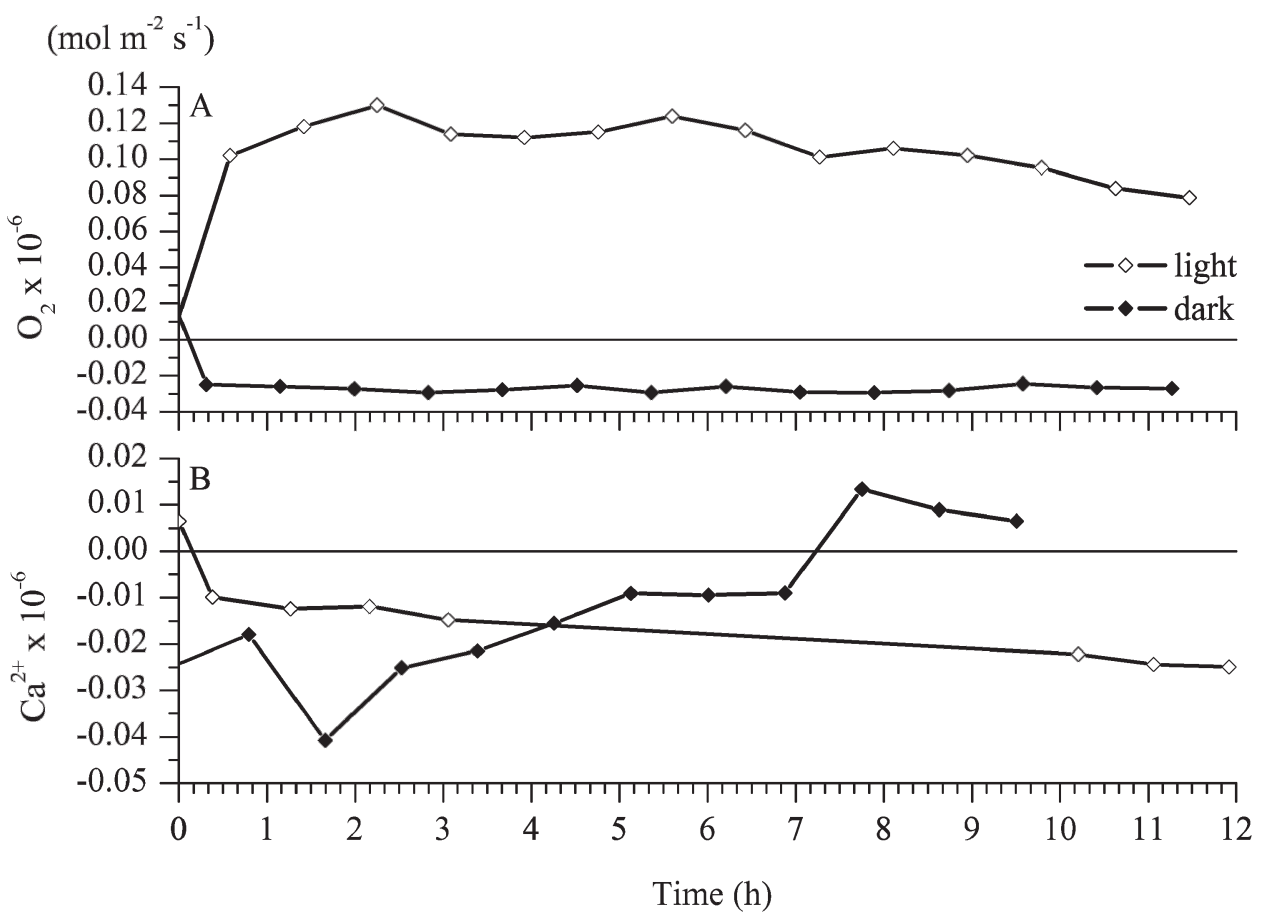

Fig. 6. The interfacial fluxes of (A) $\mathrm{O}_{2}$ and (B) $\mathrm{Ca}^{2+}$ over a diel cycle in darkness and during illumination.

hysteresis (Ewing 1885). This needs to be taken into account when calculating diurnal calcification rates and when designing in situ calcification studies in transportlimited systems.

\section{Acknowledgments}

We thank Tim Cooper from the Australian Institute of Marine Science for providing the sediment samples and Gernot Arp from the Department of Geobiology for Geosciences and Volker Karius from the Department of Sedimentology at the University of Göttingen for X-ray diffraction analysis of the sediment samples, Miriam Weber for assistance in many ways, Gaby Eickert, Ingrid Dohrmann, Karin Hohmann, Ines Schröder, and Cäcilia Wiegand for providing the sensors, and Hakhyun Nam and Byeong Hyo Kim (Kwangwoon University, Korea) for supplying the $\mathrm{CO}_{3}^{2-}$ ionophore. Stephanie Köhler-Rink and the two reviewers are thanked for helpful comments on this manuscript. The study was supported by the Max-Planck Society.

\section{References}

Arp, G., J. Hofman, and J. Reitner. 1998. Microbial fabric formation in spring mounds ('microbialites') of alkaline salt lakes in the Badain Jaran Sand Sea, PR China. Palaios 13: 581-592.

- A. Reimer, And J. Reitner. 2001. Photosynthesis-induced biofilm calcification and calcium concentrations in Phanerozoic oceans. Science 292: 1701-1704, doi:10.1126/science. 1057204.

Bissett, A., D. De Beer, R. Schoon, F. Shiraishi, A. Reimer, And G. ARP. 2008a. Microbial mediation of stromatolite formation in karst-water creeks. Limnol. Oceanogr. 53: 1159-1168.
, A. Reimer, D. De Beer, F. Shiraishi, and G. Arp. $2008 b$. Metabolic microenvironment control by photosynthetic biofilms under changing macroenvironmental temperature and $\mathrm{pH}$ conditions. Appl. Environ. Microb. 74: 6306-6312.

Boucher, G., J. Clavier, C. Hily, and J.-P. Gattuso. 1998. Contribution of soft-bottoms to community metabolism (primary production and calcification) of a barrier reef flat (Moorea, French Polynesia). J. Exp. Mar. Biol. Ecol. 225: 269-283.

Broecker, W. S., and T.-H. Peng. 1974. Gas exchange rates between air and sea. Tellus 9: 1-17.

Buffan-Dubau, E., and K. R. Carman. 2000. Diel feeding behavior of meiofauna and their relationships with microalgal resources. Limnol. Oceanogr. 45: 381-395.

Cooper, T. F., S. Uthicke, C. Humphrey, and K. E. Fabricius. 2007. Gradients in water column nutrients, sediment parameters, irradiance and coral reef development in the Whitsunday Region, central Great Barrier Reef. Estuar. Coast. Shelf. Sci. 74: 458-470.

de Beer, D., M. Kühl, N. Stambler, and L. Vaki. 2000. A microsensor study of light enhanced $\mathrm{Ca}^{2+}$ uptake and photosynthesis in the reef-building hermatypic coral Favia sp. Mar. Ecol. Prog. Ser. 194: 75-85.

EwING, J. A. 1885. Experimental researches in magnetism. Philos. Trans. R. Soc. London 176: 523-640.

Ferris, F. G., S. Schultze, T. C. Witten, W. S. Fyfe, and T. J. BEVERIDGE. 1989. Metal interactions with microbial biofilms in acidic and neutral $\mathrm{pH}$ environments. Appl. Environ. Microbiol. 55: 1249-1257.

Gattuso, J.-P., D. Allemand, and M. Frankignoulle. 1999. Photosynthesis and calcification at cellular, organismal and community levels in coral reefs: A review on interactions and control by carbonate chemistry. Am. Zool. 39: 160-183. 
, M. Pichon, B. Delesalle, C. Canon, and M. FranKIGNOUle. 1996. Carbon flux in coral reefs. I. Lagrandgian measurement of community metabolism and resulting air-sea $\mathrm{CO}_{2}$ disequilibrium. Mar. Ecol. Prog. Ser. 145: 109-121.

Hartley, A. M., W. A. House, B. S. C. Leadbeater, and M. E. CALlow. 1996. The use of microelectrodes to study the precipitation of calcite upon algal biofilms. J. Colloid Interface Sci. 183: 498-505.

Kühl, M., Y. Cohen, T. Dalsgaard, B. B. Jørgensen, and N. P. RevsBeCH. 1995. Microenvironment and photosynthesis of zooxanthellae in scleractinian corals studied with microsensor for $\mathrm{O}_{2}, \mathrm{pH}$ and light. Mar. Ecol. Prog. Ser. 117: 159-172.

Lewin, J., And R. Guillard. 1963. Diatoms. Annu. Rev. Microbiol. 17: 373-414.

Li, Y., And S. Gregory. 1974. Diffusion of ions in deep-sea sediments. Geochim. Cosmochim. Acta 38: 703-714.

Ludwig, R., F. Al-Horani, D. De Beer, And H. M. Jonkers. 2005. Photosynthesis controlled calcification in a hypersaline microbial mat. Limnol. Oceanogr. 50: 1836-1843.

Milliman, J. D. 1974. Carbonates and the ocean, p. 3-12. In J. D. Milliman, G. Müller and U. Förstner [eds.], Recent sedimentary carbonates, Part 1 . Marine carbonates. Springer.

Morse, J. 2002. Sedimentary geochemistry of the carbonate and sulphide systems and their potential influence on toxic metal bioavailability, p. 165-189. In A. Gianguzza, E. Pelizetti and S. Sammartano [eds.], Chemistry of marine water and sediments. Springer.

Müller, G. 1964. Methods of sediment analysis. E. Schweizerbart'sche Verlagsbuchhandlung. [In German.]

RevsBech, N. P. 1989. An oxygen microsensor with a guard cathode. Limnol. Oceanogr. 34: 474-478.

, B. B. Jørgensen, T. H. Blackburn, and Y. Cohen. 1983. Microelectrode studies of the photosynthesis and $\mathrm{O}_{2}, \mathrm{H}_{2} \mathrm{~S}$ and $\mathrm{pH}$ profiles of a microbial mat. Limnol. Oceanogr. 28: 1062-1074.

RIDING, R. 2000. Microbial carbonates: The geological record of calcified bacterial-algal mats and biofilms. Sedimentology 47: 179-214.

Schanz, F., And Z. Dubinsky. 1988. The afternoon depression in primary productivity in a high rate oxidation pond (HROP). J. Plankton. Res. 10: 373-383.
TuCKer, M. 1990. Geological background to carbonate sedimentation, p. 28-69. In M. E. Tucker and V. P. Wright [eds.], Carbonate sedimentology. Blackwell Scientific Publications.

Ullman, W. J., and R. C. Aller. 1982. Diffusion coefficients in nearshore marine sediments. Limnol. Oceanogr. 27: 552-556.

Uthicke, S. 2006. Photosynthetic efficiency and rapid light curves of sediment-biofilms along a water quality gradient in the Great Barrier Reef, Australia. Mar. Ecol. Prog. Ser. 322: 61-73.

Visscher, P. T., R. P. Reid, B. M. Bebout, S. E. Hoeft, I. G. Macintyre, and J. A. Thompson, JR. 1998. Formation of lithified micritic laminae in modern marine stromatolites (Bahamas): The role of sulfur cycling. Am. Mineral. 83: 1482-1493.

Walter, L. M., And E. A. Burton. 1990. Dissolution of recent platform carbonate sediments in marine pore fluids. Am. J. Sci. 290: 601-643.

Werner, U., A. Blazejak, P. Bird, G. Eickert, R. Schoon, R. Abed, A. Bissett, ANd D. DE Beer. 2008. Microbial photosynthesis in coral reef sediments (Heron Reef, Australia). Estuar. Coast. Shelf Sci. 76: 876-888, doi:10.1016/j.ecss.2007.08.015. , P. Bird, C. Wild, T. Ferdelman, L. Polerecky, G. Eickert, R. Jonstone, O. Hoegh-Guldberg, and D. De Beer. 2006. Spatial patterns of aerobic and anaerobic mineralization rates and oxygen penetration dynamics in coral reef sediments. Mar. Ecol. Prog. Ser. 305: 93-105.

Wright, S. W., AND S. W. JefFrey. 1997. High-resolution HPLC system for chlorophylls and carotenoids of marine phytoplankton, p. 327-341. In S. W. Jeffrey, R. F. C. Mantoura and S. W. Wright [eds.], Phytoplankton pigments in oceanography: Guidelines to modern methods. UNESCO.

Yates, K. K., And R. B. Halley. 2006. Diurnal variation in rates of calcification and carbonate sediment dissolution in Florida Bay. Estuar. Coasts 29: 24-39.

Zeebe, R. E., and D. Wolf-Gladrow. 2001. $\mathrm{CO}_{2}$ in seawater: Equilibrium, kinetics, isotopes. Elsevier Oceanography Series.

Associate editor: Markus H. Huettel

Received: 10 February 2009

Accepted: 03 September 2009

Amended: 16 October 2009 